\title{
COMMENT: DNA AS PROPERTY: IMPLICATIONS ON THE CONSTITUTIONALITY OF DNA DRAGNETS
}

\author{
Jonathan F. Will
}

\section{INTRODUCTION}

Joe Smith is a maintenance worker at County Hospital. One morning he reported to work to find an array of law enforcement vehicles and personnel scattered about the premises. He proceeded to his locker to prepare for work and was confronted by a policeman. Apparently an elderly female patient was sexually assaulted late one night during the previous week. The police officer informed Joe that all male employees were required to give a blood sample to rule out their implication in the assault. Joe was apprehensive and stated that because he worked first shift, he could not possibly have been involved. The police officer told Joe that a warrant would be obtained if he resisted. Reluctantly, Joe agreed, though he did not understand how a sample of his blood could help this investigation. Was Joe required to give this blood sample, and further, should he have been afforded any constitutional protections?

For over fifteen years worldwide law enforcement agencies have used DNA profiling to aid in their investigations. ${ }^{1}$ While the benefits of such technology cannot be understated, especially when it comes to ensuring that justice is served, ${ }^{2}$ civil rights can be endangered by DNA profiling. ${ }^{3}$ The use

\footnotetext{
* $\quad$ Executive Editor, University of Pittsburgh Law Review; J.D./M.A. candidate 2004, University of Pittsburgh School of Law Center for Bioethics and Health Law. The author would like to thank Dr. Rhonda Gay Hartman for her support and guidance throughout this process. Thank you to the editors of the Law Review for their tireless efforts. Finally, thank you to friends and family for your continuous love, patience, and encouragement.

1. See, e.g., Fred W. Drobner, DNA Dragnets: Constitutional Aspects of Mass DNA Identification Testing, 28 CAP. U. L. REV. 479 (2000); William C. Thompson, When Science Enters the Courtroom: The DNA-Typing Controversy, in ARE Genes Us? 180 (Carl F. Cranor ed., 1994).

2. Symposium, The Human Genome Project, DNA Science and the Law: The American Legal System's Response to Breakthroughs in Genetic Science, 51 AM. U. L. REV. 401, 404 (2002) [hereinafter Symposium].

3. There is currently little to no policy concerning the administration of DNA dragnets and the use of the information obtained there from. See Jeffrey S. Grand, Note, The Blooding of America: Privacy and the DNA Dragnet, 23 CARdozo L. REv. 2277, 2318-22 (2002) (proposing statutory guidelines for the regulation of DNA dragnets).
} 
of DNA dragnets is a paradigmatic example. ${ }^{4}$ This law enforcement strategy involves the mass DNA sampling of individuals whom authorities have neither probable cause nor reasonable suspicion to believe perpetrated the crime in question. ${ }^{5}$ It is the DNA extracted from Joe's blood sample that will aid the police in tracking down the perpetrator of the assault at County Hospital. Unlike fingerprints used for identification purposes, however, an individual's DNA contains a myriad of information about health and genetic identity that deserves increased protection. ${ }^{6}$

This comment will argue that when the state seeks to deprive a person of his or her DNA, greater constitutional protections than are currently afforded dragnets must be provided. Part I will discuss the unique properties of DNA, the information contained therein and why it should be constitutionally protected. Part II will briefly trace the history of DNA dragnets, including the practical and procedural uses in worldwide criminal investigations. Part III will explore current law and commentary regarding Fourth Amendment privacy interests in one's DNA. Part IV will argue that DNA constitutes personal property, and finally, Part V will show how recognition of property rights in DNA implicates Due Process under the Fourteenth Amendment to such an extent that the process currently used in DNA dragnets is constitutionally inadequate.

\section{The Nature of DNA And Genetic Testing}

Deoxyribonucleic acid ("DNA") is the major component of the chromosomes found in nearly every cell in the human body. ${ }^{7}$ The double helical structure is comprised of two strings of nucleotide building blocks that come in four types: adenine (A), thymine (T), cystosine (C), and guanine $(\mathrm{G}){ }^{8}$ Our genetic make-up consists of a linear sequence of these nucleotides,

4. See, e.g., Drobner supra note 1, at 479-80; Grand, supra note 3, at 2278-81.

5. See Dateline: Blood Simple; Law Enforcement Agenciesin the United Kingdom and the United States Using Mass DNA Testing to Solve Crimes (NBC television broadcast, July 19, 1998) [hereinafter Dateline]; David M. Halbfinger, Police Dragnets for DNA Tests Draw Criticism, N.Y.TIMEs, Jan. 4, 2003, at A1.

6. See infra Part I.

7. Marcus Pembrey, The New Genetics: A User's Guide, in The Troubled Helix: Social and Psychological Implications of the New Human Genetics 63, 67 (Theresa Marteau \& Martin Richards eds., 1996) (analogizing DNA within the chromosome to the tightly wound ribbon within a cassette tape. Genes are spaced along the length of the DNA molecule like individual song recordings on the tape).

8. Pembrey, supra note 7, at 67. 
and the genetic code is read three nucleotides at a time. ${ }^{9}$ The code itself, the genome, contains each individual's hereditary information as well as genetic predispositions for genetic disorders. ${ }^{10}$ Despite this complexity, over ninetynine percent of the genetic code between two individuals is identical. It is this sharing that justifies the billions of dollars spent on the Human Genome Project. ${ }^{11}$

DNA profiling works by testing the molecule's structure for variation: "Of the 3 billion nucleotides in the human genome, about one in a thousand is a site of variation, or polymorphism."12 The most common type of analysis used today is known as Restriction Fragment Length Polymorphism ("RFLP"), which identifies alterations in the length of DNA fragments. ${ }^{13}$ Upon receipt of a cell sample, for example from hair, blood, or cheek swab, a technician extracts the DNA and exposes it to a restriction enzyme, "which cuts the long chainlike DNA molecules into 'restriction fragments.", 14 These fragments are then separated and sorted by length using a process called electrophoresis. ${ }^{15}$ Radioactive probes are then used to position and bind fragments of interest, known as variable-number tandem repeats ("VNTR"). ${ }^{16}$ Law enforcement officials attempt to find matches by comparing VNTRs from the samples found at the crime scene to those obtained through sampling strategies such as the DNA dragnet. Thus, forensic DNA tests do not actually "read" the genetic code itself, they simply measure the length of restriction fragments for comparison. ${ }^{17}$

If this is the case, what privacy concerns exist? During questioning at a symposium sponsored by American University, Dr. F. Samuel Baechtel from the FBI DNA unit, conceded that "[o]nce you have the cells from someone,

9. Each triplet encodes one of the twenty amino acids that are the building blocks of protein. For example, CCT codes for proline and GAG for glutamic acid. Id.

10. Grand, supra note 3, at 2286-87.

11. Id. at 2286-87. Scientists hope that a complete mapping of the human genome will reveal the precursors to all genetic disorders, thus making one's DNA similar to a "reverse diary: it informs our younger selves about our aging selves." George J. Annas, Genetic Privacy: There Ought to Be a Law, 4 Tex. Rev. L. \& Pol. 9, 11 (1999).

12. Thompson, supra note 1, at 181 .

13. Id.

14. Id. at 182 .

15. $I d$.

16. Returning to the music metaphor, VNTRs "would be places where the record skipped and repeated a number of times before playing the rest of the tune. The number of repeats in each VNTR tends to vary from individual to individual, thus creating an RFLP." Id.

17. Id.; see also Symposium, supra note 2, at 423 (stating that " $[\mathrm{t}]$ he areas we look at don't tell us anything about the tendency to develop a disease or whether somebody already has it"). 
then the potential exists to essentially probe anywhere within that DNA." ${ }^{18}$ This means that those with access to the DNA have access to the originator's hereditary information, implicating family members as well, and to his or her genetic predispositions. The concern with DNA testing, then, lies in the potential for abuse.

Although he may not know it, Joe Smith carries the recessive gene mutation associated with Sickle Cell Anemia. Sickle Cell is an autosomal recessive disorder found with high frequency in those of African descent. ${ }^{19}$ In some parts of Africa, for instance, the carrier frequency is one out of every three, attributed to "the selective advantage it provides against a form of malaria." ${ }^{20}$ Although a carrier, Joe himself does not suffer from Sickle Cell disease.

Joe's wife is pregnant with their first child. As with all autosomal recessive disorders, if Joe's wife is also a carrier of the mutation, their child has a $25 \%$ chance of being affected with the disease, a $50 \%$ chance of being an unaffected carrier, and a $25 \%$ chance of being neither affected nor a carrier of the mutation for Sickle Cell. ${ }^{21}$

After the investigation, and at County Hospital's request, the police provided the hospital with the DNA samples taken from the employees. The hospital performed its own genetic test, and upon learning of Joe's carrier status, informed him that his wife would need to have a genetic test performed to determine her carrier status. Further, if she were found to be a carrier, ${ }^{22}$ their unborn child would also have to be tested. In the event that the child were found to be affected by the disorder, Joe's wife's pregnancy would not be covered under his insurance plan because of the child's pre-existing condition. ${ }^{23}$

The information contained on the human genome is highly personal and private in nature. ${ }^{24}$ Although the Supreme Court has yet to specifically address the rights attaching to DNA, in Griswold v. Connecticut, the Court

\footnotetext{
18. Symposium, supra note 2, at 425 .

19. Mary Briody Mahow ald, Genes, Women, Equality 179 (2000).

20. Id.

21. See id. at 163 .

22. If Joe's wife is not a carrier, there is no chance that their child could be affected by Sickle Cell. See id.

23. See Glenn McGee, The Perfect Baby: A Pragmatic Approach to Genetics 96 (1997) (arguing that insurance providers should not be permitted to apply "pre-existing condition" status to fetuses because it wrongly assumes that the gene is the same as the disease).

24. Annas, supra note 11, at 13 (stating that "genetic information is uniquely private and should be protected by law"); Grand, supra note 3, at 2309.
} 
first recognized constitutionally protected "zones of privacy," ${ }^{25}$ later expanded to include an interest in preventing the disclosure of intimately personal information. ${ }^{26}$ One can hardly deny the intimate and personal nature of the information contained in the human genome- "anything from a person's medical conditions and predispositions to her mental attributes." ${ }^{27}$ The potential that this information might be disclosed to employers or insurance companies poses the risk of an "intrinsic dignitary harm" to the individual. ${ }^{28}$ For example, the information obtained from Joe's blood sample led to the subjection of his family to prying inquiries from his employer and the threat of losing health insurance to cover his wife's pregnancy. Given these potential ramifications, the procedure used to obtain Joe's DNA warrants heightened scrutiny.

\section{The History and Procedure of DNA Dragnets}

The law enforcement personnel gathered at County Hospital were carrying out a DNA dragnet. The first recorded use of mass DNA sampling occurred in the small village of Narborough, England in 1986. ${ }^{29}$ After the rape and murder of two teenage girls, the police sought voluntary DNA samples from over 4,500 men in the surrounding area. ${ }^{30}$ Ironically, the true perpetrator confessed and was convicted only after he raised suspicion with the police by convincing another man to submit a sample in his place. ${ }^{31}$

Since the Narborough incident, DNA dragnets expanded to continental Europe. In 1998 the largest known mass DNA test was performed in Strueklingen, Germany, where 16,400 individuals were sampled in connection with the rape and murder of an eleven-year-old girl. ${ }^{32}$ In this case, authorities eventually found a match with a man who had a prior rape conviction.

The practice has also developed in the United States. One of the larger samples was taken in Dade County, Florida in an attempt to apprehend the "Tamiami Strangler," a killer of six prostitutes who dumped his victims'

25. Griswold v. Connecticut, 381 U.S. 479, 484 (1965).

26. Whalen v. Roe, 429 U.S. 589, 599-600 (1977).

27. Grand, supra note 3, at 2312.

28. Id. at 2313 .

29. Angus J. Dodson, Comment, DNA “Line-Ups" Based on a Reasonable Suspicion Standard, 71 U. CoLo. L. Rev. 221, 223 (2000).

30. Id. at 224 .

31. Drobner, supra note 1, at 479.

32. Id. at 481 . 
bodies outside the city of Miami. ${ }^{33}$ In Florida, 2,300 men were tested in 1995, but the perpetrator was not among them. ${ }^{34}$ Other DNA dragnets were carried out on a smaller scale in San Diego, California, ${ }^{35}$ Ann Arbor, Michigan, ${ }^{36}$ Prince George's County, Maryland, ${ }^{37}$ and Lawrence, Massachusetts. ${ }^{38}$ Although these investigations vary in size and geographic location, they "share one common trait - they are based on the fact that investigators have not been able to focus suspicion on any particular individual as having probably committed the crime. ${ }^{39}$ By their very nature, DNA dragnets obtain private, personal — and possibly incriminating — information from individuals without probable cause or even reasonable suspicion.

\section{Search and Seizure Under the Fourth Amendment}

The Fourth Amendment provides:

The right of the people to be secure in their persons, houses, papers, and effects, against unreasonable searches and seizures, shall not be violated, and no Warrants shall issue, but upon probable cause, supported by Oath or affirmation, and particularly describing the place to be searched, and the persons or things to be seized. ${ }^{40}$

This Amendment is implicated upon a showing that those involved in DNA dragnets have an expectation of privacy, and that such searches and seizures are unreasonable.

In Katz v. United States, the Supreme Court recognized that the Fourth Amendment protects "people — and not simply 'areas'—against unreasonable searches and seizures." ${ }^{41}$ In his concurring opinion, Justice Harlan suggested

33. Id. at 482 .

34. Id. The culprit was eventually apprehended after a subsequent attempted rape. Id.

35. Id. at 481 (stating that samples were taken from 800 men matching the general description of a dark-skinned male in 1990).

36. Halbfinger, supra note 5, at A8 (stating that 160 samples were obtained from black men after the rape of thirteen women in 1994).

37. Id. (stating that 400 male workers at a county hospital where an administrator had been raped were tested in 1998).

38. Id. (stating that samples taken from thirty-two men at a nursing home where a resident had been raped and impregnated in 1999).

39. Drobner, supra note 1 , at 482.

40. U.S. Const. amend. IV.

41. Katz v. United States, 389 U.S. 347, 353 (1967). In Katz police used a listening device to eavesdrop on a phone booth conversation. $I d$. at 348 . The Court held that individuals should be secure from searches conducted "only in the discretion of the police," as these violate the Fourth Amendment. Id. at 359 (citing Beck v. Ohio, 379 U.S. 89, 97 (1964)). 
a two-fold requirement, "first that a person have exhibited an actual (subjective) expectation of privacy and, second, that the expectation be one that society is prepared to recognize as "reasonable." ${ }_{42}$ Given the nature of the information contained in one's DNA, it is likely that society would find it reasonable to expect privacy in this area.

During dragnets, DNA is generally collected through either blood samples or the cheek swab popularized by television programs. ${ }^{43}$ In light of this, the Supreme Court's ruling in Schmerber v. California is central. ${ }^{44}$ Schmerber was hospitalized after having been in an automobile accident. Believing alcohol was involved, police took a blood sample without a warrant or his consent. ${ }^{45}$ The Supreme Court acknowledged that the "overriding function of the Fourth Amendment is to protect personal privacy and dignity against unwarranted intrusion by the State." ${ }^{46}$ For intrusions going beyond the body's surface, the Fourth Amendment requires more than "mere chance that desired evidence might be obtained," such that "fundamental human interests require law officers to suffer the risk that such evidence may disappear unless there is an immediate search. ${ }^{\prime 47}$ Further, because warrants are required for searches of dwellings, "no less could be required where intrusions into the human body are concerned." ${ }^{\prime \prime 8}$ Although the Court in Schmerber ultimately found in favor of the policeman, ${ }^{49}$ by limiting its analysis to the facts presented by the record, it underscored " $[t]$ he integrity of an individual's person" as a "cherished value of our society." 50

The Court's language in Schmerber seems to imply that blood samples obtained from DNA dragnets violate the Fourth Amendment. Because not even reasonable suspicion exists to suggest that the individuals tested were involved in the crime, the police have nothing more than a "mere suspicion" that evidence will result from DNA samples taken beyond the body's surface.

42. Id. at 361; see also Grand, supra note 3, at 2289 n.58 (citing subsequent Supreme Court opinions adopting Justice Harlan's test).

43. E.g., Michael P. Jewkes, Note, Just Scratching the Surface: DNA Sampling Prior to Arrest and the Fourth Amendment, 35 Suffolk U. L. Rev. 125, 140 (2001).

44. Schmerber v. California, 384 U.S. 757 (1966).

45. Id. at 758-59.

46. Id. at 767 .

47. Id. at 770

48. Id.

49. Id. at 770-72 (holding that the policeman's actions were reasonable given the exigency of the circumstances).

50. Id. at 772 . 
By its very nature, DNA is carried in the cells of individuals for their entire life; thus, exigent circumstances also do not exist.

The Supreme Court used a balancing test to determine the constitutionality of blood and urine testing for drugs by the Federal Railroad Administration. ${ }^{51}$ The Court held that the Fourth Amendment was implicated without an actual intrusion into the body, but determined that the seizures were justified without a warrant or probable cause due to the government's strong interest in preventing accidents. ${ }^{52}$ The permissibility of a search is "judged by balancing its intrusion on the individual's Fourth Amendment interests against its promotion of legitimate governmental interests," beyond the needs of law enforcement. ${ }^{53}$

While the government has a strong interest in keeping rapists and murderers off the streets, the use of DNA dragnets is not an acceptable procedure to do so. The Fourth Amendment is meant to protect individuals' privacy and dignity, and removing one's DNA has the potential to intrude on privacy and dignity in a very harmful way. Focusing on the testing involved in Skinner, the Court acknowledged safety as an immediate governmental interest beyond law enforcement. ${ }^{54}$ Because DNA dragnets cannot promise to identify the perpetrator of the crime, ${ }^{55}$ thereby removing the dangerous person from the streets, no government interest beyond the traditional law enforcement interest is realized by this procedure.

Based on the Supreme Court's reasoning in Schmerber and Skinner, the taking of bodily fluids or genetic material from an individual for testing is a search constitutionally protected by the Fourth Amendment. ${ }^{56}$ Fourth Amendment guarantees, however, do not protect against all searches and seizures; only unreasonable ones. Searches performed with the consent of the individual are reasonable. ${ }^{57}$ For example, if the dragnets are carried out with the consent of those from whom samples are taken, they are likely reasonable.

\footnotetext{
51. Skinner v. Ry. Labor Executives' Ass'n, 489 U.S. 602, 619 (1989).

52. Id. at 623-24 (recognizing, also, the exigency of testing the fluids before the drug content dissipated).

53. Vernonia Sch. Dist. v. Acton, 515 U.S. 646, 652-53 (1995) (quoting Delaware v. Prouse, 440 U.S. 648, $654(1979))$.

54. Skinner, 489 U.S. at 620.

55. See supra Part II and accompanying text. In many of the dragnets performed, the perpetrator's DNA was not obtained from the actual dragnet itself. $I d$.

56. Grand, supra note 3, at 2302.

57. Florida v. Jimeno, 500 U.S. 248, 250-51 (1991) (stating "we have long approved consensual searches because it is no doubt reasonable for the police to conduct a search once they have been permitted to do so").
} 
A superficial finding of consent does not end the inquiry, however, because consent is only voluntary when given in the absence of duress or coercion..$^{58}$ Voluntariness is determined on a case-by-case basis considering objective and subjective factors such as age, education, knowledge of the right to refuse, and whether threats or physical punishment were used to induce consent. ${ }^{59}$ In considering the surrounding circumstances, "account must be taken of the subtly coercive police questions, as well as the possibly vulnerable subjective state of the person who consents." ${ }^{\prime 60}$ Joe Smith's limited education-an important factor in the Bustamonte analysis ${ }^{61}$-made him vulnerable and prevented him from understanding the significance of his submitting to the blood sample.

The consent obtained by law enforcement officers involved in DNA dragnets is questionably coercive. Several of the men tested in Ann Arbor, Michigan claimed to have been harassed by police, who told them that the only way to clear their names was to submit to testing. ${ }^{62}$ One participant reported that he was told that, if he did not cooperate, a court order would be obtained. ${ }^{63}$ Similarly, in Maryland, two maintenance workers who were detained in separate rooms felt coerced by the procedure having been "told" that they would give a DNA sample, not asked if one could be collected. ${ }^{64}$

It is also impermissible for police to feign authority that they do not have. In Bumper v. North Carolina, the Supreme Court held that the consent given by an elderly woman to police claiming to have a search warrant was not valid. ${ }^{65}$ The Court stated, "[w]hen a law enforcement officer claims authority to search a home under a warrant, he announces in effect that the occupant has no right to resist the search. The situation is instinct with coercion . . ." ${ }^{96}$ Similarities between Bumper and the aforementioned DNA dragnets suggest that the consent obtained for many of these samples was not voluntary, and therefore, constitutionally suspect.

Nonetheless, in the absence of consent, reasonableness can be found upon a balancing of intrusiveness against government interest. ${ }^{67}$ In Davis $v$.

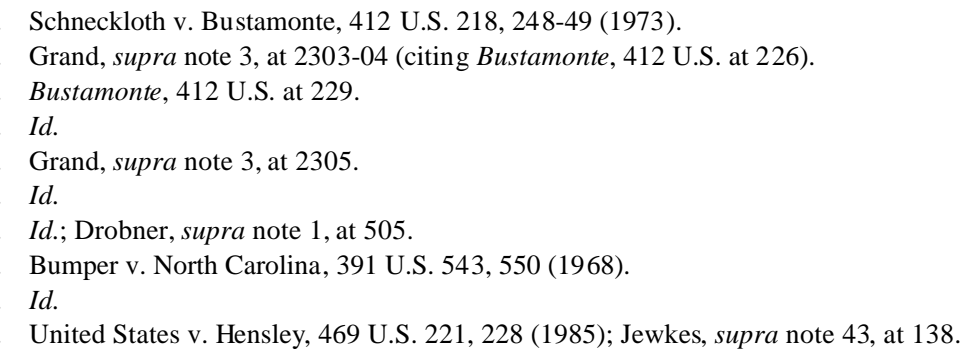


Mississippi, the Supreme Court stated that fingerprinting may "constitute a much less serious intrusion upon personal security than other types of police searches and detentions," and "involves none of the probing into an individual's private life and thoughts that marks an interrogation or search." ${ }^{\circ 8}$ Dicta from this case left the door open for the possibility that fingerprinting without probable cause or a warrant could be reasonable under the Fourth Amendment in some instances, though those instances were not spelled out. ${ }^{69}$

It is worth noting that the DNA identification process has been called "DNA fingerprinting." ${ }^{70}$ Unlike typical fingerprinting, the Supreme Court has yet to rule on the extent of invasiveness involved in DNA samplings. However, a few lower federal and state courts have addressed the issue. For example, in United States v. Nicolosi, a federal district court concluded that probable cause is necessary for the swabbing of the inner cheek to obtain a saliva sample. ${ }^{71}$ The court began its analysis by acknowledging that three state supreme courts require both probable cause and a search warrant for the collection of saliva. ${ }^{72}$ The court concluded that obtaining blood or other internal bodily fluids "requires full compliance with Fourth Amendment procedures. These items are not in the public domain and privacy and dignitary interests are implicated by the method of obtaining the sample.",73 The Supreme Court of Vermont, on the other hand, held that this procedure is not highly invasive. ${ }^{74}$

There is a marked difference between one's fingerprints and one's DNA. In Davis, the Court noted that fingerprints do not probe into an individual's private life. ${ }^{75}$ Because of the unique characteristics of genetic material and the information contained therein, such as medical conditions and gene mutations, one's private life is intimately tied to his or her DNA. ${ }^{76}$ In Joe Smith's case, access to his DNA allowed his employer to delve into not only his private life,

68. Davis v. Mississippi, 394 U.S. 721, 727 (1969); Grand, supra note 3, at 2294; Dodson, supra note 29 , at 235 .

69. Grand, supra note 3, at 2294.

70. Drobner, supra note 1, at 480; Dodson, supra note 29, at 227.

71. United States v. Nicolosi, 885 F. Supp. 50, 55 (E.D.N.Y. 1995).

72. Id. at 54 (citing State v. Ostroski, 518 A.2d 915 (Conn. 1986); State v. Reeves, 671 P.2d 553 (Kan. 1983); Pyle v. State, 645 P.2d 1390 (Okla. Crim. App. 1982)).

73. Id. at 55 .

74. See In re Nontestimonial Identification Order Directed to R.H., 762 A.2d 1239 (Vt. 2000); but see Jewkes, supra note 43, at 142 (claiming that the Vermont court mistakenly relied upon a combination of dicta in Davis, 394 U.S. at 727, with the ruling in Terry v. Ohio, 392 U.S. 1 (1968)).

75. See supra notes $68-69$ and accompanying text.

76. See supra Part I. 
but also that of his family. Beyond the Fourth Amendment, ${ }^{77}$ further protection could be offered to individuals faced with situations like Joe Smith's by attaching property rights to DNA.

\section{DNA As the Property of its Originator}

Very few cases have addressed property rights in relation to a person's organs, tissue, and genetic material. ${ }^{78}$ The seminal case in this area is Moore v. Regents of the University of California. ${ }^{79}$ John Moore sought treatment at the University of California at Los Angeles Medical Center ("UCLA") for hairy-cell leukemia, and David Golde, the attending physician, recommended a splenectomy to slow the progression of the disease. ${ }^{80}$ Evidence showed that before the operation Golde was aware that, due to their rare nature, certain of Moore's blood products and components were of significant commercial value. ${ }^{81}$ After the procedure Moore was informed that his treatment required follow-up testing, which he participated in for seven years. ${ }^{82}$ During that time, Golde and his associate, Shirley Quan, removed tissue, sperm, bone marrow, blood, and other samples from Moore. ${ }^{83}$ Throughout the seven years, Moore was presented with complex consent forms relinquishing any rights in the cell lines and derivatives created by Golde and Quan. ${ }^{84}$ From the research performed on Moore's tissues, Golde and Quan created and patented the "MO" cell line. ${ }^{85}$ As a result, they entered into commercial contracts with

77. Drobner, supra note 1, at 507-10, suggests that the Fifth Amendment privilege against selfincrimination might also be implicated by DNA dragnets. As he points out, however, the Supreme Court in Schmerber held that the blood the defendant was compelled to submit was "real or physical evidence," not testamentary in nature, and therefore, not protected by the Fifth Amendment. Id. at 508. If the Supreme Court was willing to say that Schmerber's incriminating blood test was nontestimonial, the same would likely hold for incriminating DNA evidence. $I d$. at 509. Drobner did suggest the possibility that the process itself might be violative of the Fifth Amendment. Id. at 509-10. In some instances police conceded that failure to submit to the test would raise suspicion about the individual, implying that denying the police could serve to incriminate the targeted persons. Id.

78. Michael M.J. Lin, Note and Comment, Conferring a Federal Property Right in Genetic Material: Stepping into the Future with the Genetic Privacy Act, 22 Am. J.L. \& Med. 109, 110 (1996).

79. Moore v. Regents of the Univ. of Cal., 793 P.2d 479 (Cal. 1990).

80. Id. at 481 .

81. Id.

82. $I d$.

83. $I d$.

84. Id.

85. $I d$. 
biotechnology companies and received more than $\$ 400,000$ for access to a potential market estimated at over $\$ 3.01$ billion. ${ }^{86}$

Eventually, Moore became suspicious and refused to sign one of Golde and Quan's extensive consent forms ${ }^{87}$ Moore ultimately brought a thirteencount action against Golde, Quane, Regents, and UCLA including a claim for conversion of property. ${ }^{88}$ After a hearing, the trial court sustained Regent's demurrer on the conversion claim. ${ }^{89}$ On appeal, the court held that Moore had established a claim for conversion, and thus, recognized that Moore had a property interest in his bodily tissue..$^{90}$

In so finding, the California appellate court held that " "property" refers not to a particular material object but to the right and interest or domination rightfully obtained over such object, with the unrestricted right to its use, enjoyment and disposition." ${ }^{11}$ The court explained that there is a right of dominion over one's body and the interests therein, and that " $[t]$ hese rights and interests are so akin to property interests that it would be a subterfuge to call them something else." ${ }^{, 2}$

The Supreme Court of California ultimately reversed the appellate court's finding on this point. ${ }^{93}$ The court concluded that Moore's consent to the splenectomy amounted to an abandonment and relinquishment of any rights over the tissues involved. ${ }^{94}$ As a matter of policy, the court was concerned that holding otherwise would have a chilling effect on research and the biotechnology industry. ${ }^{95}$

It is important to realize that the ruling in Moore dealt with tissue and material that had already been removed from the individual's body. ${ }^{96}$ By speaking in terms of abandonment, the Supreme Court of California seemed to suggest that, before the tissue was removed, Moore did have a property interest in it. ${ }^{97}$ Justice Broussard proffered a dissenting opinion due to the

86. Lin, supra note 78 , at 113.

87. $I d$.

88. Moore, 793 P.2d at 481.

89. Moore v. Regents of the Univ. of Cal., 249 Cal. Rptr. 494, 501 (Cal. Ct. App. 1988), rev'd, Moore v. Regent of the Univ. of Cal., 793 P.2d 479 (Cal. 1990).

90. Id. at 503-10.

91. Id. at 504 .

92. Id. at 505 .

93. See Moore, 793 P.2d at 497.

94. Id. at 489 .

95. Id. at 487 ; see also Lin, supra note 78 , at 114 (discussing a recognition of property rights in DNA for research and commercial purposes).

96. Moore, 793 P.2d at 488-89.

97. Id. at 489 . 
majority's failure to acknowledge the distinction between bodily tissue before and after its removal. ${ }^{98}$ His dissent acknowledged that part of Moore's complaint dealt with his bodily tissue prior to removal, and as such, the majority should not have rejected his conversion claim. ${ }^{99}$ Because the majority of the court was not more explicit in Moore, there is concern that biotechnology will have "free reign," and that the ruling "fails to adequately protect a patient-donor's individual liberties." 100

In order to address this shortcoming in genetic research, the Genetic Privacy Act ("GPA") was prepared by the U.S. Department of Energy's Ethical, Legal, and Social Issues Working Group ("ELSI") of the Human Genome Project, and proposed as a model for uniform adoption. ${ }^{101}$ Interestingly, the GPA clearly states that DNA is the property of the individual from whom it was obtained. ${ }^{102}$ Although the GPA was never widely adopted, ${ }^{103}$ it attempts to address the concerns surrounding genetic research and privacy today.

\section{Due Process and the Fourteenth Amendment}

In the area of research, arguments have been raised that DNA should be afforded the protections of property law. This comment has attempted to show that the interest one has in his or her genetic information remains constant whether in the research or criminal investigation setting. Affording individuals property rights in their DNA implicates further protection under the Fourteenth Amendment regarding DNA dragnets. In relevant part, this Amendment provides that no state shall "deprive any person of life, liberty, or property, without due process of law." 104

The Fourteenth Amendment invokes a two-part inquiry. First, did a state actor deprive an individual of life, liberty, or property. If the answer is yes,

98. Id. at 501 (Broussard, J., dissenting).

99. Id.

100. Lin, supra note 78, at 130; see also Michael Orlando, Moore Revisited: State-Sponsored Biotechnological Research and the Takings Clause, 23 WhitTIER L. REV. 437, 453 (2001).

101. Patricia Roche et al., The Genetic Privacy Act: A Proposal for National Legislation, 37 Jurimetrics J. 1, 4 (1996); see also Richard L. Furman, Jr., Comment, Genetic Test Results and the Duty to Disclose: Can Medical Researchers Control Liability, 23 SeAttle U. L. Rev. 391, 398 (1999).

102. Roche, supra note 101 , at 4.

103. See generally Lin, supra note 78, at 128-34; Orlando, supra note 100, at 453; Natalie Anne Stepanuk, Comment, Genetic Information and Third Party Access to Information: New Jersey's Pioneering Legislation as a Model for Federal Privacy Protection of Genetic Information, 47 CATH U. L. REV. 1105, 1116 n.46 (1998) (detailing New Jersey's modification and adoption of the GPA).

104. U.S. Const. amend. XIV. 
one must consider what process is due when such a deprivation occurs. The Supreme Court has held that when an individual's property rights are at stake the minimum process due is "notice and the opportunity to be heard." 105 So what process is due when police seek to deprive individuals of their DNA?

The process Joe Smith received in the deprivation of his DNA, common in dragnets, was insignificant. Without a warrant, probable cause, or even reasonable suspicion, Joe was told that he had to submit to a blood sample. When law enforcement officers seek to deprive an individual of property pursuant to a criminal investigation more process is required than that given during a DNA dragnet.

The Fourth Amendment provides that persons are protected from unreasonable searches and seizures. Reasonableness is presumed, when, after sufficient process, a warrant is obtained. ${ }^{106}$ The Supreme Court has held that "in the ordinary case, seizures of personal property are unreasonable within the meaning of the Fourth Amendment, without more, unless . . . accomplished pursuant to a judicial warrant."107

The Court went on to acknowledge exceptions to the warrant requirement: ${ }^{108}$ the search of an automobile supported by probable cause, ${ }^{109}$ suspicionless stops at drunk driver checkpoints, ${ }^{110}$ the temporary seizure of luggage based upon reasonable suspicion, ${ }^{111}$ temporary detention of a suspect without an arrest warrant in order to prevent flight and protect officers as they executed a search warrant, ${ }^{112}$ and temporary stop and limited search for weapons based on reasonable suspicion. ${ }^{113}$ None of these exceptions apply to DNA dragnets. ${ }^{114}$

Using strictly Fourth Amendment analysis would permit a court to use the dicta in Davis v. Mississippi to apply a reasonableness inquiry to DNA dragnets. In so doing, courts could allow police to subject individuals to DNA testing without a warrant, probable cause, reasonable suspicion, or any

105. Dusenbery v. United States, 534 U.S. 161, 167 (2002) (citing United States v. James Daniel Good Real Property, 510 U.S. 43, 48 (1993)).

106. See U.S. Const. amend. IV; see, e.g., Katz v. United States, 389 U.S. 347, 357 (1967).

107. Illinois v. McArthur, 531 U.S. 326, 330 (2001) (citing United States v. Place, 462 U.S. 696, 701 (1983)).

108. Id. at 330-31.

109. Pennsylvania v. Labron, 518 U.S. 938, 940-41 (1996) (per curiam).

110. Mich. Dep't of State Police v. Sitz, 496 U.S. 444, 455 (1990).

111. Place, 462 U.S. at 706.

112. Michigan v. Summers, 452 U.S. 692, $702-05$ (1981).

113. Terry v. Ohio, 392 U.S. 1, 27 (1968).

114. See supra Part II (by definition DNA dragnets are performed without probable cause or reasonable suspicion and no exigent circumstances exist given the permanence of DNA in the body). 
exception. ${ }^{115}$ Attaching property rights to DNA limits the extent to which a court may focus on reasonableness by requiring a warrant unless an exception exists. ${ }^{116}$ Because none of the exceptions exist in the dragnet setting, a Supreme Court ruling that DNA is the property of its originator would require warrants to be obtained prior to its removal. Given its unique characteristics and the information contained therein, more is at stake and more protection is due when the state seeks to deprive an individual of DNA.

\section{CONCLUSION}

Due to the intimate and identifiable information contained in DNA, the collection of DNA samples without a warrant, probable cause, or reasonable suspicion raises constitutional concerns. To date, opponents have used a Fourth Amendment search and seizure analysis coupled with concerns for privacy to argue against the use of DNA dragnets. ${ }^{117}$ While these arguments are meritorious and persuasive, dicta in Davis v. Mississippi presents the risk that obtaining DNA through dragnets might be found reasonable under the Fourth Amendment. Recognizing property rights in DNA would require state actors to obtain a warrant before subjecting individuals to testing, because no exception to this general rule applies to DNA dragnets. This comment has attempted to bridge the gap between concerns in criminal law and genetic research, ${ }^{118}$ further buttressing the claim that these sorts of random profilings should be avoided.

As in Joe Smith's case, access to genetic information through DNA testing provides the potential for abuse of extremely private and personal information. Proper law enforcement techniques should not be thwarted, but the use of dragnets to obtain this information from individuals when there is no warrant, probable cause, nor reasonable suspicion to believe they are implicated in a crime, is constitutionally unacceptable. The state has an avenue for accessing such information, and following the proper procedure - the warrant-DNA may be acceptably obtained.

115. See supra Part III.

116. See supra notes $107-15$.

117. See supra notes 1-4 and accompanying text.

118. E.g., Lin, supra note 78; Orlando, supra note 100. 